\title{
SISTEM PENDUKUNG KEPUTUSAN PRIORITAS PERBAIKAN GEDUNG MENGGUNAKAN METODE ANALYTIC HIERARCHY PROCESS DAN PROFILE MATCHING
}

\author{
Muhammad Hamka ${ }^{1}$, Harjono ${ }^{2}$, \\ Program Studi S1 Teknik Informatika, Universitas Muhammadiyah Purwokerto
}

\section{Informasi Makalah}

Dikirim, 27 April 2019

Direvisi, 29 April 2019

Diterima, 30 April 2019

\section{Kata Kunci:}

Sistem Pendukung Keputusan Analytic Hierarchy Process Profile Matching Indeks Kondisi Sub Elemen Indeks Kondisi Elemen Indeks Kondisi Komponen

\begin{abstract}
INTISARI
Gedung bertingkat memiliki banyak sub elemen, elemen, sub komponen dan komponen di tiap bagian struktur, arsitektur, dan utilitasnya. Kerna kompleksnya elemen dan sub elemen di dalam bangunan gedung bertingkat, sehingga diperlukan rencana kegiatan dan mekanisme yang terencana untuk menentukan prioritas perbaikan. Penelitian ini mengkaji implementasi Sistem Pendukung Keputusan (SPK) untuk menentukan prioritas perbaikan gedung berdasarkan aspek kerusakan pada sub elemen, elemen, dan komponen. Metode SPK yang digunakan yaitu Analytic Hierarchy Process (AHP) dan Profile Matching. Metode AHP digunakan untuk menentukan priority vector atau bobot prioritas sub elemen, elemen, dan komponen, sedangkan Profile Matching digunakan untuk menentukan perangkingan gedung yang menjadi prioritas perbaikan berdasarkan pengukuran volume kerusakan, jenis kerusakan, nilai pengurang dan faktor koreksi serta nilai Skala Indeks Kondisi Mckay pada sub elemen, elemen dan komponen gedung.
\end{abstract}

Berdasarkan hasil proses Profile Matching, didapatkan nilai total aspek struktur gedung 1 yaitu 1,05 , gedung 2 yaitu 1,5 , dan gedung 3 yaitu 0,75 , untuk nilai total aspek struktur gedung 1 yaitu 1,40, gedung 2 yaitu 1,20 dan gedung 3 yaitu 1,50 , sedangkan nilai total aspek utilitas gedung 1 yaitu gedung 1 yaitu 0 , gedung 2 yaitu 1,5 , dan gedung 3 yaitu 0 . Sehingga berdasarkan persamaan 10, diperoleh rangking prioritas pertama perbaikan gedung yaitu gedung 2 dengan nilai 1,36, prioritas kedua yaitu gedung 1 dengan nilai 1,05, dan prioritas ketiga adalah gedung 3 dengan nilai 0,98 .

\section{Keyword:}

Decision Support System Analytic Hierarchy Process Profile Matching Condition Index of Sub Element Condition Index of Element Condition Index of Component

\begin{abstract}
The storey building has many sub-elements, elements, sub-components and components in each part of its structure, architecture, and utilities. Because of the complexity of elements and sub-elements in a storey building, a plan of activities and a planned mechanism are needed to determine the priority of renovation. This research study the implementation of Decision Support Systems (SPK) to determine the priority of building improvement based on aspects of damage to sub elements, elements, and components. The DSS's method were used namely the Analytic Hierarchy Process (AHP) and Profile Matching. AHP method was used to determine priority vectors or priority weights of sub-elements, elements, and components, while Profile Matching was used to determine building ranking priority restorations based on measurement of damage volume, type of damage, deduction value and correction factor with Mckay Condition Index Scale value on sub elements, elements and components of the building.

Based on the results of the Profile Matching process, the total value of the aspect structure as follows : building 1 is 1.05 , building 2 is 1.5 , and building 3 is 0.75 , while the total value of the structural aspects namely : building 1 is 1.40 , building 2 is 1.20 and building 3 is 1.50 . In Addition, total value of the utility aspects are building 1 is 0 , building 2 is 1.5 , and building 3 is 0 . According to equation 10, the first priority ranking of building improvement is building 2 with value of 1.36 , the second priority is building 1 with a value of 1.05 , while the third priority is building 3 with a value of 0.98 .
\end{abstract}




\section{Korespondensi Penulis:}

Muhammad Hamka

Program Studi S1 Teknik Informatika

Universitas Muhammadiyah Purwokerto

JL. Raya Dukuhwaluh PO. BOX 202 Purwokerto, 53182

Email: muhammadhamka@ump.ac.id

\section{INTRODUCTION}

Bangunan khususnya gedung bertingkat memiliki beberapa komponen, yaitu struktur, arsitektur, dan utilitas [1]. Struktur bangunan meliputi sub komponen struktur atas, struktur atap, dan struktur bawah. Elemen yang masuk ke dalam struktur yaitu kuda-kuda, rangka atap, ikatan angin, kolom, balok, pelat, kolom, balok, dan sloof. Arsitektur gedung menurut Undang-undang Republik Indonesia Nomor 28 Tahun 2002 tentang Bangunan Gedung pasal 9 ayat 1 meliputi aspek penampilan bangunan gedung, tata ruang dalam, keseimbangan, keserasian, dan keselarasan gedung dengan lingkungannya, serta pertimbangan adanya keseimbangan antara nilai-nilai sosial budaya setempat terhadap penerapan berbagai perkembangan arsitektur dan rekayasa [2]. Sedangkan Uitlitas bangunan merupakan suatu kelengkapan fasilitas bangunan yang digunakan untuk menunjang tercapainya unsur kenyamanan, kesehatan, keselamatan, kemudahan komunikasi dan mobilitas dalam bangunan [3].

Kompleksnya elemen dan sub elemen di dalam bangunan gedung bertingkat memerlukan mekanisme untuk menentukan prioritas perbaikan dan perbaikan masing-masing elemen. Untuk menentukan prioritas pemeliharaan dan perbaikan gedung yang tepat sasaran serta sesuai alokasi anggaran, maka diperlukan rencana kegiatan dan mekanisme yang terencana dan berkala. Berdasarkan paparan diatas, maka dalam penelitian ini akan dikaji penerapan Sistem Pendukung Keputusan (SPK) penentuan prioritas pemeliharaan dan perbaikan gedung bangunan bertingkat dengan menggunakan Composite Condition Index (CCI) dan Profile Matching. Metode Profile Matching merupakan metode yang tepat dalam menentukan prioritas pemeliharaan dan perbaikan gedung karena terdapat tingkat ideal variabel prediktor yang harus dipenuhi oleh kompetensi alternatif [4], dalam hal ini adalah hasil penilaian kondisi gedung. Selain itu, metode Analytic Hierarchy Process (AHP) juga digunakan untuk menentukan bobot prioritas tiap elemen dan sub elemen, di dalam proses penentuan prioritas perbaikan gedung. AHP adalah metode pengambilan keputusan memiliki beberapa kelebihan, terutama ketika melibatkan beberapa atrribut dan preferensi [5], yang memungkinkan pembuat keputusan untuk menyederhanakan masalah menjadi struktur hierarkis berdasarkan persepsi manusia [6]. Lebih lanjut, Ho dan Xin menyatakan bahwa metode AHP mudah dipahami, jelas, dan sangat adaptif [7] ketika diterapkan di dalam berbagai bidang seperti pendidikan [8] untuk penentuan proses pengajaran yang tepat di lembaga pendidikan tinggi [9], penentuan prioritas manajemen teknologi informasi yang saat ini digunakan dan tingkat manajemen teknologi informasi yang diharapkan yang terlibat dalam fase berikutnya [10], serta di bidang pertanian untuk menentukan prioritas model produksi dan pemasaran yang sesuai berdasarkan rantai pasokan pertanian [11].

\section{METODOLOGI}

\subsection{Desain Penelitian}

Desain penelitian yang akan dilakukan mengacu pada model konseptual SPK. SPK tersusun oleh beberapa komponen sub sistem, yaitu manajemen data, manajemen model, manajemen dialog, dan manajemen knowledge base [12]. Desain penelitian ditunjukkan pada gambar 1 . 


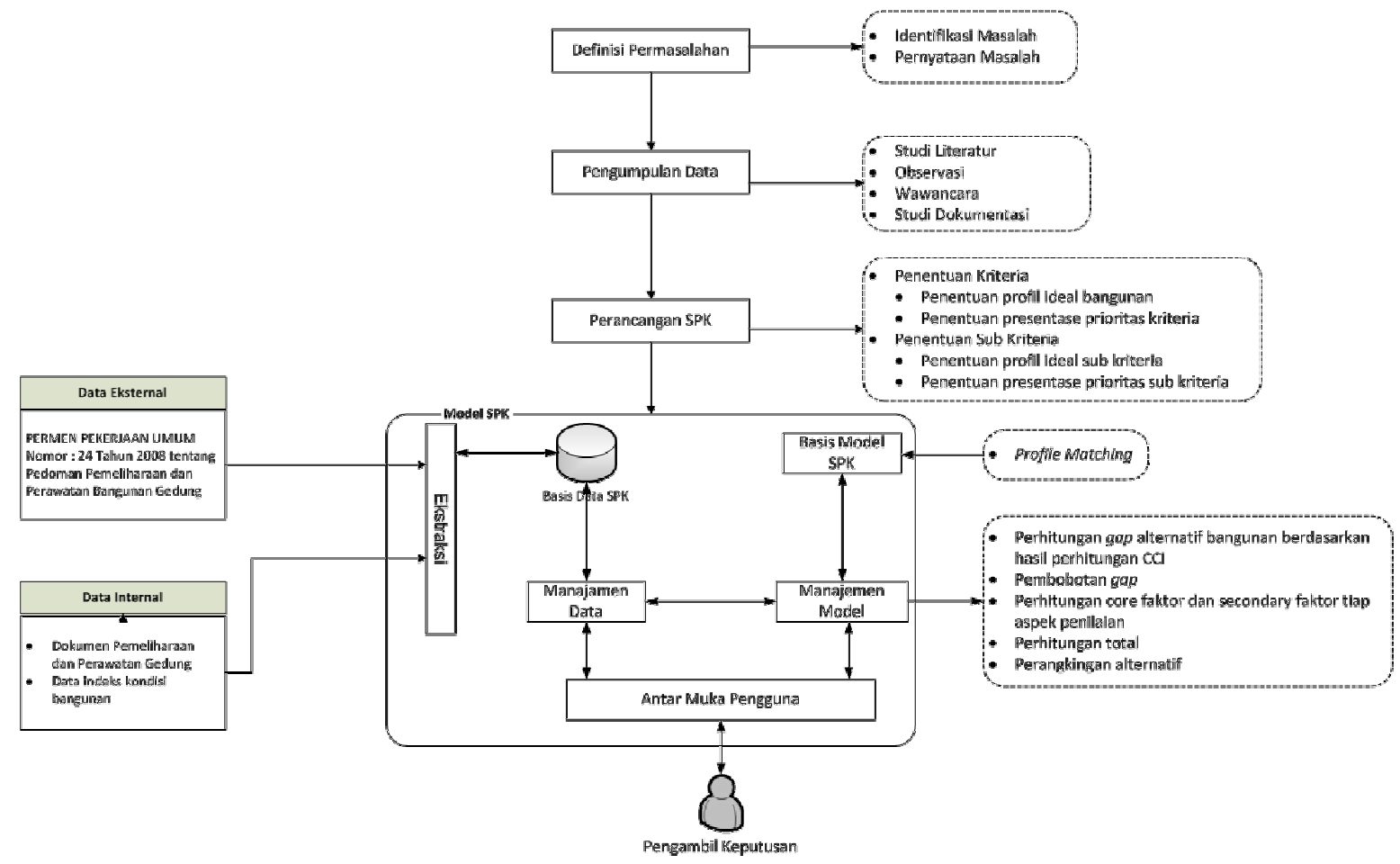

Gambar 1. Desain Penelitian

Berdasarkan gambar 1, tahapan-tahapan di dalam penelitian ini, yaitu :

a. Definisi Permasalahan

Fase identifikasi permasalahan merupakan tahap di mana permasalahan-permasalahan pada kegiatan pemeliharaan dan perbaikan bangunan gedung khususnya pada bangunan gedung bertingkat diidentifikasi. Selain itu, pada fase ini juga ditentukan tujuan dan ruang lingkup penelitian, identifikasi kemungkinan penyelesaian permasalahan penentuan prioritas pemeliharaan dan perbaikan bangunan gedung melalui implementasi Sistem Pendukung Keputusan (SPK), dan penentuan metode SPK yang akan digunakan.

b. Pengumpulan Data

Sumber data yang dikumpulkan dalam penelitian ini merupakan data internal, data eksternal, dan data private. Data internal meliputi dokumen pemeliharaan dan perbaikan bangunan gedung, data aset bangunan gedung, serta data indeks kondisi bangunan gedung di lingkungan Universitas Muhammadiyah Purwokerto, Provinsi Jawa Tengah pada tahun 2017. Data eksternal meliputi undang-undang dan peraturan-peraturan yang terkait bangunan gedung. Sedangkan data private merupakan aspek-aspek penilaian yang ditentukan di dalam pengembangan SPK ini, data private meliputi data jenis kerusakan, data kerusakan bangunan, faktor koreksi, nilai Indeks Kondisi Sub Elemen, nilai Indeks Kondisi Elemen, dan nilai Indeks Kondisi Komponen yang memerlukan tindakan perbaikan mengacu pada nilai Skala Indeks Kondisi Mckay [1]. Menurut jenis datanya, metode pengumpulan data dalam penelitian ini adalah sebagai berikut :

\section{1) Data Primer}

Data primer merupakan data yang diambil langsung dari obyek penelitian. Teknik pengumpulan data primer dilakukan melalui teknik observasi dan wawancara terkait proses penentuan prioritas perbaikan dan perbaikan bangunan gedung yang selama ini berjalan.

2) Data Sekunder

Data sekunder merupakan data telah dikumpulkan oleh pihak lain berupa hasil perhitungan atau dokumen-dokumen terkait perhitungan nilai indeks kondisi bangunan gedung. Teknik pengumpulan data sekunder dilakukan dengan cara studi dokumentasi dan studi literatur.

c. Perancangan Sistem Pendukung Keputusan

Metode SPK yang digunakan di dalam penelitian ini adalah AHP dan Profile Matching. Tahapan-tahapan dalam implementasi Profile Matching pada penelitian ini adalah sebagai berikut:

1) Perhitungan bobot prioritas tiap elemen, sub elemen, komponen dan sub komponen gedung menggunakan metode AHP

2) Perhitungan Indeks Kondisi Sub Elemen

3) Perhitungan Indeks Kondisi Elemen

4) Perhitungan gap kondisi sub elemen gedung

5) Perhitungan gap kondisi elemen gedung

6) Penentuan dan perhitungan nilai Core Factor dan Secondary Factor 
7) Perhitungan total

8) Penentuan rangking prioritas pemeliharaan dan perbaikan bangunan gedung

\subsection{Penilaian Kondisi Sub Elemen dan Elemen Gedung}

Perhitungan Indeks Kondisi Sub Elemen (IKSE) merupakan perhitungan untuk menilai kondisi elemen yang berada pada tingkatan paling bawah pada struktur hirarki bangunan [1]. Indeks Kondisi Elemen dihitung menggunakan persamaan 1 [13].

$I K S E=100-\sum_{i=1}^{p} \sum_{j=1}^{m} \alpha\left(T_{j}, S_{j}, D_{i j}\right) * F(t, d)$

Keterangan :

$\alpha \quad$ : nilai pengurang

$\mathrm{p} \quad$ : jumlah jenis kerusakan untuk kelompok sub elemen yang ditinjau

m : jumlah tingkat kerusakan untuk jenis kerusakan

$F(t, d) \quad$ : faktor koreksi untuk kerusakan berganda yang berbeda

Nilai pengurang $(\alpha)$ memiliki besaran antara 0 (nol) hingga 100 (seratus) tergantung pada jenis kerusakan $\left(T_{j}\right)$, tingkat kerusakan $\left(S_{j}\right)$, dan volumen kerusakan $\left(D_{i j}\right)$ [1]. Sedangkan nilai faktor koreksi untuk jenis kerusakan lebih dari satu mengacu pada Uzarski di dalam Kusnadi [1]. Nilai faktor koreksi untuk kerusakan berganda ditunjukkan pada tabel 1.

Tabel 1. Faktor Koreksi untuk Kombinasi Kerusakan

\begin{tabular}{cccc}
\hline No. & $\begin{array}{c}\text { Jumlah Kombinasi } \\
\text { Kerusakan }\end{array}$ & $\begin{array}{c}\text { Prioritas Bahaya } \\
\text { Kerusakan }\end{array}$ & $\begin{array}{c}\text { Faktor Koreksi } \\
\mathrm{F}(\mathrm{t}, \mathrm{d})\end{array}$ \\
\hline 1 & 2 & I & $0,8-0,7-0,6$ \\
& & II & $0,2-0,3-0,4$ \\
2 & 3 & I & $0,5-0,6$ \\
& & II & $0,3-0,4$ \\
& & III & $0,1-0,2$ \\
\hline
\end{tabular}

Setelah nilai IKSE diketahui, selanjutnya dilakukan perhitungan Indeks Kondisi Elemen (IKE). IKE dihitung menggunakan persamaan 2 [13].

$I K E=I K S E_{1} \times B S E_{1}+I K S E_{2} \times B S E_{2}+\cdots+I K S E_{r} \times B S E_{r}$

Keterangan:

IKSE : Indeks Kondisi Sub Elemen,

BSE : Bobot Fungsional Sub Elemen,

r : Banyaknya sub elemen.

Bobot fungsional sub elemen merupakan hasil perhitungan menggunakan metode AHP, dimana tingkat kepentingan tiap bobot fungsional sub elemen mengacu pada hasil penelitian yang dilakukan oleh Kusnadi [1]. Nilai IKSE untuk sub elemen yang tidak mengalami kerusakan adalah 0 (nol) hingga 100 (seratus) untuk tingkat kerusakan paling tinggi [1].

\subsection{Penilaian Indeks Kondisi Komponen (IKK)}

Penilaian IKK untuk tiap komponen struktur, arsitektur dan utilitas didapatkan melalui penjumlahan Indeks Kondisi Elemen dikalikan bobot tiap elemen. IKK dihitung menggunakan persamaan 3.

$I K K=I K E_{1} * B E_{1}+I K E_{2} * B E_{2}+\cdots+I K E_{t} * B E_{t}$

Keterangan :

IKE $\quad$ : Indeks Kondisi Elemen

BE : Bobot Elemen

t : banyaknya elemen

\subsection{Analytic Hierarchy Process}

Metode Analytic Hierarchy Process (AHP) di dalam penelitian ini digunakan untuk menentukan bobot atau priority vector tiap sub elemen, elemen, dan komponen gedung. Langkah-langkah di dalam penentuan bobot tiap sub elemen gedung di dalam AHP adalah sebagai berikut :

1) Melakukan perbandingan berpasangan untuk tiap sub elemen menggunakan skala 1-9 Saaty seperti ditunjukkan pada tabel 2 [14]. 
Tabel 2. Skala Penilaian Perbandingan Berpasangan

\begin{tabular}{|c|c|c|}
\hline $\begin{array}{l}\text { Intensity of } \\
\text { importance }\end{array}$ & Definition & Explanation \\
\hline 1 & Equal importance & $\begin{array}{l}\text { Two activities contribute equally to the } \\
\text { objective }\end{array}$ \\
\hline 3 & Moderate importance & $\begin{array}{l}\text { Experience and judgment slightly favor } \\
\text { one activity over another }\end{array}$ \\
\hline 5 & Strong importance & $\begin{array}{l}\text { Experience and judgment strongly favor } \\
\text { one activity over another }\end{array}$ \\
\hline 7 & $\begin{array}{l}\text { Very strong or demonstrated } \\
\text { importance }\end{array}$ & $\begin{array}{l}\text { An activity is favored very strongly over } \\
\text { another; its dominance demonstrated in } \\
\text { practice }\end{array}$ \\
\hline 9 & Extreme importance & $\begin{array}{l}\text { The evidence favoring one activity over } \\
\text { another is of the highest possible order of } \\
\text { affirmation }\end{array}$ \\
\hline $2,4,6,8$ & $\begin{array}{l}\text { notion between two proximate } \\
\text { values }\end{array}$ & $\begin{array}{l}\text { This value is specified when options are } \\
\text { adjacent. For instance, } 4 \text { is given in- } \\
\text { between } 3 \text { and } 5\end{array}$ \\
\hline $\begin{array}{l}\text { Reciprocals } \\
\text { of above }\end{array}$ & $\begin{array}{l}\text { If activity } i \text { has one of the } \\
\text { above nonzero numbers } \\
\text { assigned to it when compared } \\
\text { with activity } j \text {, then } j \text { has the } \\
\text { reciprocal value when } \\
\text { compared with } i\end{array}$ & \\
\hline
\end{tabular}

2) Synthesis of Priority, digunakan untuk memperoleh keseluruhan prioritas tiap sub elemen dengan melakukan normalisasi matrik keputusan hasil perbandingan berpasangan dan mencari nilai rata-rata tiap sub elemen.

3) Logical Consistency, digunakan untuk mengukur tingkat konsistensi hasil perbandingan berpasangan. Ketidakkonsistenan dapat disebabkan oleh kurangnya informasi ketika menilai prioritas kriteria atau adanya unsur subjektivitas dari pengambil keputusan. analisis hasil perbandingan berpasangan dinilai konsisten jika nilai Consistency Ratio (CR) tidak lebih dari $10 \%$ [13]. Langkah-langkah pengukuran tingkat konsistensi adalah sebagai berikut :

a) Mengalikan tiap nilai dalam matrik perbandingan berpasangan dengan nilai priority vector yang sesuai untuk mendapatkan matrik normalisasi terbobot.

b) Menghitung nilai eigenvector $(\lambda)$. Nilai eigenvector didapatkan dari rata-rata pembagian antara matrik normalisasi terbobot dengan nilai priority vector.

c) Menghitung nilai CR menggunakan persamaan 4.

$C I=\frac{(\lambda-n)}{(n-1)}$

Dimana :
CI $\quad$ : Consistency Index
$\lambda \quad$ : eigenvector
$\mathrm{n} \quad$ : jumlah kriteria atau sub elemen

d) Menghitung nilai Consistency Ratio (CR) menggunakan persamaan 5.

$C . R=\frac{C I}{R . I}$

Nilai random consistency index (R.I.) ditentukan berdasarkan tabel 3 [14].

Table 3. Random Consistency Index (R.I)

\begin{tabular}{ccccccccccc}
\hline $\mathrm{N}$ & 1 & 2 & 3 & 4 & 5 & 6 & 7 & 8 & 9 & 10 \\
\hline $\begin{array}{c}\text { Random consistency } \\
\text { index (R.I.) }\end{array}$ & 0 & 0 & 0.52 & 0.89 & 1.11 & 1.25 & 1.35 & 1.40 & 1.45 & 1.49 \\
\hline
\end{tabular}

\subsection{Profile Matching}

Penentuan urutan alternatif pada model Profile Matching berdasarkan tingkat profil alternatif yang paling mendekati profil ideal [14]. Tahapan-tahapan di dalam penentuan keputusan menggunakan Profile Matching adalah sebagai berikut :

1) Perhitungan Gap

Gap adalah hasil perbedaan kompetensi antara profil alternatif dan profil target [4]. Gap dapat dihitung menggunakan persamaan 6 .

Gap = Nilai Profil Alternatif - Nilai Profil Target

2) Pembobotan

Nilai gap semua alternatif terhadap masing-masing profil ideal merupakan masukan untuk proses pembobotan. Pembobotan adalah proses pemberian nilai bobot pada nilai gap berdasarkan tabel 4 [15]. 
Tabel 4. Tabel Bobot Nilai Gap

\begin{tabular}{cccl}
\hline No. & Nilai Gap & Nilai Bobot & \multicolumn{1}{c}{ Keterangan } \\
\hline 1 & 0 & 5 & Tidak ada selisih (sesuai profil target) \\
2 & 1 & 4,5 & Profil alternatif melebihi 1 tingkat \\
3 & -1 & 4 & Profil alternatif kekurangan 1 tingkat \\
4 & 2 & 3,5 & Profil alternatif melebihi 2 tingkat \\
5 & -2 & 3 & Profil alternatif kekurangan 2 tingkat \\
6 & 3 & 2.5 & Profil alternatif melebihi 3 tingkat \\
7 & -3 & 2 & Profil alternatif kekurangan 3 tingkat \\
8 & 4 & 1,5 & Profil alternatif melebihi 4 tingkat \\
9 & -4 & 1 & Profil alternatif kekurangan 4 tingkat \\
\hline
\end{tabular}

3) Identifikasi dan perhitungan nilai Core Factor (CF) dan Secondary Factor (SF)

Setiap aspek penilaian dikelompokkan menjadi dua, yaitu core factor dan secondary factor. Core factor merupakan elemen bangunan yang paling penting di dalam struktur bangunan. Sedangkan secondary factor adalah item-item selain aspek yang ada pada core factor atau bisa juga disebut sebagai faktor pendukung pada struktur bangunan. Pengelompokan core factor dan secondary factor pada elemen bangunan ditunjukkan pada tabel 5. Nilai masing-masing variabel core factor dan secondary factor dihitung berdasarkan nilai bobot gap [15]. Nilai core factor dihitung berdasarkan persamaan 7 [4].

$N C F=\frac{\sum_{i=1}^{n} N C}{\sum_{i=1}^{n} I C}$

Dimana :

NCF : Nilai Core Factor

NC : Jumlah total nilai core factor

IC : Jumlah variabel core factor

Sedangkan nilai secondary factor dihitung berdasarkan persamaan 8 [4].

$N S F=\frac{\sum_{i=1}^{n} N S}{\sum_{i=1}^{n} I S}$

Tabel 5. Pengelompokan Core Factor dan Secondary Factor

\begin{tabular}{clll}
\hline No. & \multicolumn{1}{c}{ Komponen } & \multicolumn{1}{c}{ Elemen } & \multicolumn{1}{c}{ Core/Secondary } \\
\hline 1 & Arsitektur & Pintu & secondary \\
2 & Arsitektur & Jendela & secondary \\
3 & Struktur & Struktur Atap & core \\
4 & Arsitektur & Lantai dan Keramik & secondary \\
5 & Arsitektur & Jendela & secondary \\
6 & Struktur & Struktur Atas & core \\
7 & Utilitas & Instalasi Listrik & core \\
8 & Arsitektur & Plafond & core \\
9 & Arsitektur & Dinding & core \\
10 & Arsitektur & Penutup Atap & core \\
\hline
\end{tabular}

4) Perhitungan nilai total

Perhitungan nilai total mempertimbangkan tiap-tiap aspek yang diperkirakan berpengaruh pada kinerja tiap-tiap profil melalui nilai presentase dari core factor dan secondary factor [14]. Rumus perhitungan nilai total menggunakan persamaan 9.

$N=(x) \% N C F+(x) \% N S F$

5) Perhitungan untuk penentuan rangking alternatif

Langkah terakhir dari model profile matching adalah penentuan urutan ranking alternatif gedung yang direkomendasikan dilakukan perbaikan. Perhitungan ranking mempertimbangkan presentase prioritas tiap aspek penilaian. Rumus perhitungan ranking urutan alternatif menggunakan persamaan 10 [15].

rangking $=(x) \% N_{1}+(x) \% N_{2}+. .+(x) \% N_{n}$

\section{HASIL DAN PEMBAHASAN}

Berdasarkan hasil pengumpulan data kerusakan sub elemen pada tiga bangunan gedung, diketahui jenis kerusakan, volume kerusakan, dan nilai pengurangnya untuk menghitung nilai Indeks Kondisi Sub Elemen (IKSE). Nilai pengurang ditetapkan berdasarkan volume kerusakan pada tiap jenis kerusakan sub elemen [1]. Beberapa data kerusakan pada ketiga bangunan gedung tersebut ditunjukkan pada tabel 6. 
Tabel 6. Data Kerusakan Gedung

\begin{tabular}{|c|c|c|c|c|c|c|c|}
\hline No. & Gedung & Komponen & Elemen & Sub Elemen & Kerusakan & $\begin{array}{c}\text { Vol. } \\
\text { Kerusakan } \\
\end{array}$ & $\begin{array}{c}\text { Nilai } \\
\text { Pengurang } \\
\end{array}$ \\
\hline 1 & Gedung 1 & Struktur & Struktur atas & Kolom & Lendut & 15 & 25 \\
\hline 2 & Gedung 1 & Struktur & Struktur atas & Kolom & Retak & 44 & 38 \\
\hline 3 & Gedung 1 & Arsitektur & Pintu & Kusen Pintu & $\begin{array}{l}\text { Lapuk/Dimakan } \\
\text { Rayap }\end{array}$ & 76 & 100 \\
\hline 4 & Gedung 1 & Arsitektur & Pintu & Kusen Pintu & Pecah & 45 & 75 \\
\hline 5 & Gedung 1 & Arsitektur & Lantai dan Keramik & Keramik Lantai & Pecah & 35 & 50 \\
\hline 6 & Gedung 1 & Arsitektur & Lantai dan Keramik & Keramik Lantai & Lepas & 35 & 50 \\
\hline 7 & Gedung 1 & Arsitektur & Dinding & Cat dinding & Terkelupas & 78 & 100 \\
\hline 8 & Gedung 1 & Arsitektur & Dinding & Cat dinding & Warna pudar & 43 & 75 \\
\hline 9 & Gedung 1 & Utilitas & Instalasi listrik & Stop kontak & Pecah & 35 & 100 \\
\hline 10 & Gedung 2 & Arsitektur & Penutup atap & Genteng & Pecah & 49 & 75 \\
\hline 11 & Gedung 2 & Arsitektur & Penutup atap & Genteng & Retak & 33 & 50 \\
\hline 12 & Gedung 2 & Arsitektur & Pintu & Engsel pintu & Lepas & 76 & 75 \\
\hline 13 & Gedung 2 & Arsitektur & Pintu & Engsel pintu & Macet & 44 & 75 \\
\hline 14 & Gedung 2 & Arsitektur & Pintu & Daun pintu & Lapuk & 30 & 50 \\
\hline 15 & Gedung 2 & Arsitektur & Pintu & Daun pintu & Pecah & 15 & 50 \\
\hline 16 & Gedung 2 & Arsitektur & Lantai dan keramik & Lantai keramik & Lepas & 49 & 75 \\
\hline 17 & Gedung 2 & Arsitektur & Lantai dan keramik & Lantai keramik & Retak & 66 & 100 \\
\hline 18 & Gedung 3 & Struktur & Struktur atap & Reng & Lapuk & 77 & 100 \\
\hline 19 & Gedung 3 & Struktur & Struktur atap & Reng & Pecah & 55 & 100 \\
\hline 20 & Gedung 3 & Struktur & Struktur atap & Usuk & Pecah & 77 & 100 \\
\hline 21 & Gedung 3 & Struktur & Struktur atap & Usuk & Lapuk & 65 & 100 \\
\hline 22 & Gedung 3 & Arsitektur & Dinding & Pasangan bata & Retak & 68 & 100 \\
\hline 23 & Gedung 3 & Arsitektur & Dinding & Pasangan bata & Pecah & 44 & 75 \\
\hline 24 & Gedung 3 & Arsitektur & Plafon & Penutup plafon & Lendut & 23 & 8 \\
\hline 25 & Gedung 3 & Arsitektur & Plafon & Penutup plafon & Lapuk & 55 & 75 \\
\hline 26 & Gedung 3 & Utilitas & Instalasi listrik & Saklar & Pecah & 76 & 100 \\
\hline
\end{tabular}

\subsection{Perhitungan IKSE tiap Gedung}

Berdasarkan data-data kerusakan, jenis kerusakan, volume kerusakan, dan nilai pengurang sub elemen pada tiap gedung pada tabel 5 dapat dihitung nilai indeks kondisi sub elemennya menggunakan persamaan 1 . Hasil perhitungan nilai IKSE ditunjukkan pada tabel 7.

Tabel 7. Nilai IKSE tiap Gedung

\begin{tabular}{cclllc}
\hline No. & Gedung & Komponen & \multicolumn{1}{c}{ Elemen } & \multicolumn{1}{c}{ Sub Elemen } & IKSE \\
\hline 1 & Gedung 1 & Struktur & Struktur atas & Kolom & 69,8 \\
2 & Gedung 1 & Arsitektur & Pintu & Kusen Pintu & 10 \\
3 & Gedung 1 & Arsitektur & Lantai dan Keramik & Keramik Lantai & 50 \\
4 & Gedung 1 & Arsitektur & Dinding & Cat dinding & 7,5 \\
5 & Gedung 1 & Utilitas & Instalasi listrik & Stop kontak & 0 \\
6 & Gedung 2 & Arsitektur & Penutup atap & Genteng & 35 \\
7 & Gedung 2 & Arsitektur & Pintu & Engsel pintu & 25 \\
8 & Gedung 2 & Arsitektur & Pintu & Daun pintu & 50 \\
9 & Gedung 2 & Arsitektur & Lantai dan keramik & Lantai keramik & 17,5 \\
10 & Gedung 3 & Struktur & Struktur atap & Reng & 0 \\
11 & Gedung 3 & Struktur & Struktur atap & Usuk & 0
\end{tabular}




\begin{tabular}{lllllc}
12 & Gedung 3 & Arsitektur & Dinding & Pasangan bata & 7,5 \\
13 & Gedung 3 & Arsitektur & Plafon & Penutup plafond & 65,2 \\
14 & Gedung 3 & Utilitas & Instalasi listrik & Saklar & 0 \\
\hline
\end{tabular}

\subsection{Perhitungan bobot tiap sub elemen dan elemen gedung menggunakan AHP}

Bobot prioritas tiap sub elemen, elemen dan komponen gedung harus terlebih dahulu diketahui untuk perhitungan IKE sesuai persamaan 2. Berdasarkan proses perbandingan perpasangan tiap sub elemen dan tiap elemen yang dilakukan oleh Kusnadi [13], priority vector tiap sub elemen dan elemen ditampilkan pada tabel 8.

Tabel 8. Hasil Bobot Prioritas Sub Elemen dan Elemen Gedung

\begin{tabular}{lclc}
\hline Elemen & Bobot Elemen & Sub Elemen & Bobot Sub Elemen \\
\hline Struktur atas & 0,379 & Kolom & 0,417 \\
Pintu & 0,256 & Kusen Pintu & 0,276 \\
& & Engsel pintu & 0,06 \\
& & Daun pintu & 0,371 \\
Lantai dan Keramik & 0,147 & Keramik Lantai & 0,735 \\
Dinding & 0,253 & Cat dinding & 0,105 \\
& & Pasangan bata & 0,591 \\
Instalasi listrik & 0,412 & Stop kontak & 0,12 \\
& & Saklar & 0,118 \\
Penutup atap & 0,232 & Genteng & 0,765 \\
Struktur atap & 0,321 & Reng & 0,391 \\
& & Usuk & 0,535 \\
Plafon & 0,112 & Penutup plafon & 0,345 \\
\hline
\end{tabular}

\subsection{Perhitungan IKE tiap Gedung}

Berdasarkan hasil perhitungan IKSE dan bobot prioritas sub elemen pada tabel 8 dapat dihitung nilai Indeks Kondisi Elemen (IKE). Hasil perhitungan IKE ditunjukkan pada tabel 9.

Tabel 9. Hasil Perhitungan IKE tiap Gedung

\begin{tabular}{ccllc}
\hline No. & Gedung & Komponen & \multicolumn{1}{c}{ Elemen } & IKE \\
\hline 1 & Gedung 1 & Struktur & Struktur atas & 29,11 \\
2 & Gedung 1 & Arsitektur & Pintu & 2,76 \\
3 & Gedung 1 & Arsitektur & Lantai dan Keramik & 36,75 \\
4 & Gedung 1 & Arsitektur & Dinding & 0,79 \\
5 & Gedung 1 & Utilitas & Instalasi listrik & 0,00 \\
6 & Gedung 2 & Arsitektur & Penutup atap & 26,78 \\
7 & Gedung 2 & Arsitektur & Pintu & 20,05 \\
9 & Gedung 2 & Arsitektur & Lantai dan keramik & 12,86 \\
10 & Gedung 3 & Struktur & Struktur atap & 0,00 \\
12 & Gedung 3 & Arsitektur & Dinding & 4,43 \\
13 & Gedung 3 & Arsitektur & Plafon & 22,49 \\
14 & Gedung 3 & Utilitas & Instalasi listrik & 0,00 \\
\hline
\end{tabular}

\subsection{Perhitungan Gap}

Perhitungan gap tiap elemen pada masing-masing gedung berdasarkan nilai kondisi standar gedung pada zona 2, yaitu mulai terjadi deteriorasi atau kerusakan namun tidak mempengaruhi fungsi struktur bangunan secara keseluruhan [16]. Perhitungan gap aspek komponen struktur ditunjukkan pada tabel 10, perhitungan gap aspek komponen arsitektur ditunjukkan pada tabel 11, dan perhitungan gap aspek komponen utilitas ditunjukkan pada tabel 12. 


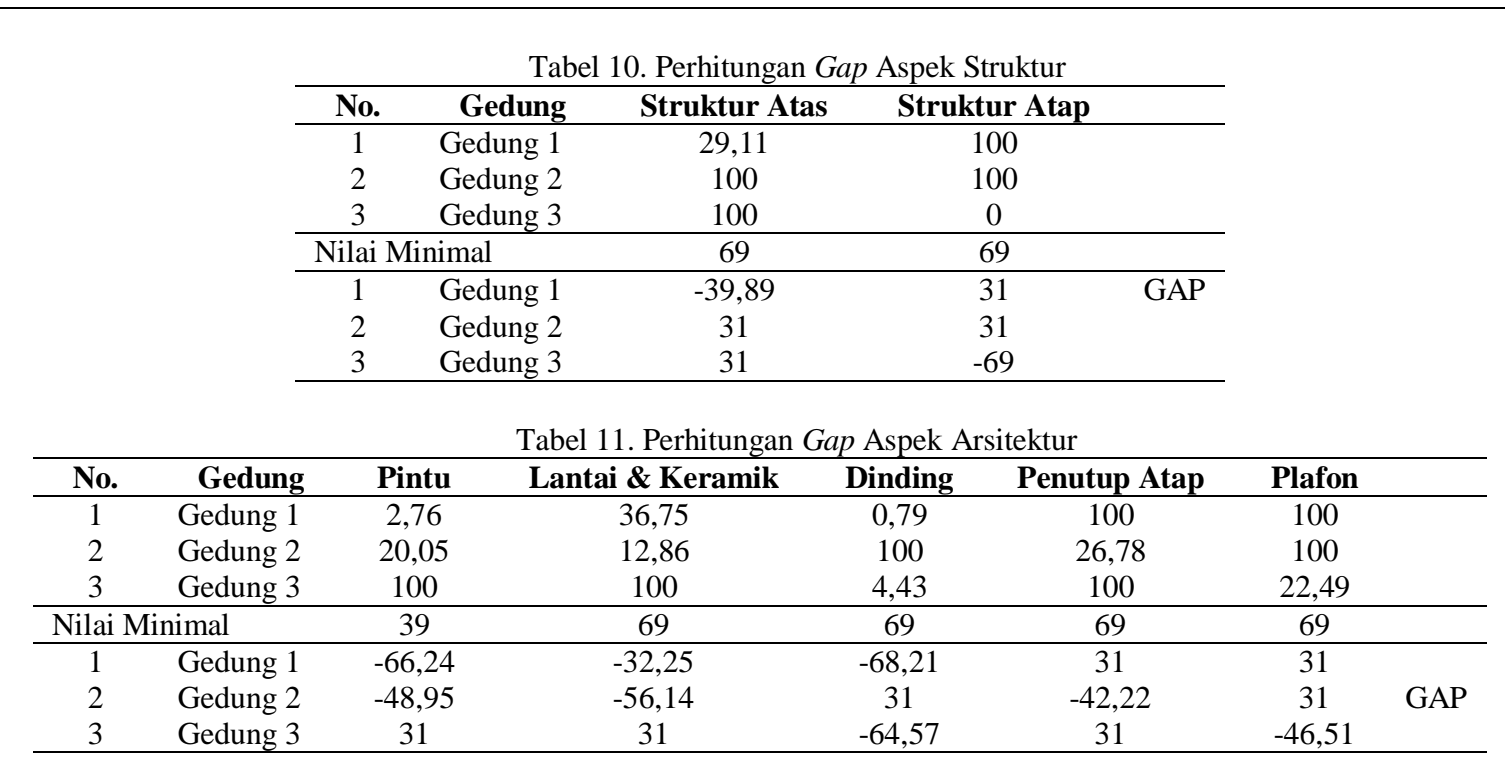

Tabel 12. Perhitungan Gap Aspek Utilitas

\begin{tabular}{cccc}
\hline No. & Gedung & Instalasi Listrik & \\
\hline 1 & Gedung 1 & 0 & \\
2 & Gedung 2 & 100 & \\
3 & Gedung 3 & 0 & \\
\hline Nilai Minimal & 69 & \\
\hline 1 & Gedung 1 & -69 & GAP \\
2 & Gedung 2 & 31 & \\
3 & Gedung 3 & -69 & \\
\hline
\end{tabular}

\subsection{Pembobotan hasil gap}

Bobot gap ditentukan berdasarkan tabel 4. Sebelumnya nilai gap terlebih dahulu dibagi 10 karena skala bobot gap pada tabel 4 adalah -4 hingga 4 . Bobot gap aspek struktur ditunjukkan pada tabel 13, aspek arsitektur ditunjukkan pada tabel 14, dan aspek utilitas pada tabel 15.

Tabel 13. Pembobotan Gap Aspek Struktur

\begin{tabular}{cccc}
\hline No. & Gedung & Struktur Atas & Struktur Atap \\
\hline 1 & Gedung 1 & 1 & 2,5 \\
2 & Gedung 2 & 2,5 & 2,5 \\
3 & Gedung 3 & 2,5 & 0 \\
\hline
\end{tabular}

Tabel 14. Pembobotan Gap Aspek Arsitektur

\begin{tabular}{ccccccc}
\hline No. & Gedung & Pintu & Lantai \& Keramik & Dinding & Penutup Atap & Plafon \\
\hline 1 & Gedung 1 & 0 & 2 & 0 & 2,5 & 2,5 \\
2 & Gedung 2 & 0 & 0 & 2,5 & 1 & 2,5 \\
3 & Gedung 3 & 2,5 & 2,5 & 0 & 2,5 & 0 \\
\hline
\end{tabular}

\begin{tabular}{ccc} 
Tabel & 15. Pembobotan & Gap Aspek Utilitas \\
\hline No. & Gedung & Instalasi Listrik \\
\hline 1 & Gedung 1 & 0 \\
2 & Gedung 2 & 2,5 \\
3 & Gedung 3 & 0 \\
\hline
\end{tabular}

\subsection{Perhitungan nilai core factor dan secondary factor}

Perhitungan nilai core factor dan secondary factor mengacu pada persamaan 7 dan 8 . Perhitungan nilai core factor (CF) dan secondary factor (SF) aspek struktur, arsitektur, dan utilitas ditunjukkan pada tabel 16, 17, dan 18.

Tabel 16. Perhitung CF dan SF Aspek Struktur

\begin{tabular}{cccccc}
\hline No. & Gedung & Struktur Atas & Struktur Atap & CF & SF \\
\hline 1 & Gedung 1 & 1 & 2,5 & 1,75 & 0 \\
2 & Gedung 2 & 2,5 & 2,5 & 2,5 & 0 \\
3 & Gedung 3 & 2,5 & 0 & 1.25 & 0 \\
\hline
\end{tabular}


Tabel 17. Perhitung CF dan SF Aspek Arsitektur

\begin{tabular}{ccccccccc}
\hline No. & Gedung & Pintu & Lantai \& Keramik & Dinding & Penutup Atap & Plafon & CF & SF \\
\hline 1 & Gedung 1 & 0 & 2 & 0 & 2,5 & 2,5 & 1,67 & 1 \\
2 & Gedung 2 & 0 & 0 & 2,5 & 1 & 2,5 & 2,00 & 0 \\
3 & Gedung 3 & 2,5 & 2,5 & 0 & 2,5 & 0 & 0,83 & 2,5 \\
\hline
\end{tabular}

Tabel 18. Perhitung CF dan SF Aspek Utilitas

\begin{tabular}{ccccc}
\hline No. & Gedung & Instalasi Listrik & CF & SF \\
\hline 1 & Gedung 1 & 0 & 0 & 0 \\
2 & Gedung 2 & 2,5 & 2,5 & 0 \\
3 & Gedung 3 & 0 & 0 & 0 \\
\hline
\end{tabular}

\subsection{Perhitungan nilai total}

Perhitungan nilai total mempertimbangkan tiap-tiap aspek yang diperkirakan berpengaruh pada kinerja tiap-tiap profil melalui nilai presentase dari core factor dan secondary factor [14], pada penelitian ini presentase core factor adalah $60 \%$, sedangkan presentase secondary factor adalah $30 \%$. Perhitungan nilai total berdasarkan persamaan 9. Hasil perhitungan nilai total aspek struktur, arsitektur, dan utilitas ditunjukkan pada tabel 19, 20, dan 21.

Tabel 19. Perhitungan Nilai Total Aspek Struktur

\begin{tabular}{ccccc}
\hline No. & Gedung & CF & SF & Nilai Struktur \\
\hline 1 & Gedung 1 & 1,75 & 0 & 1,05 \\
2 & Gedung 2 & 2,5 & 0 & 1,5 \\
3 & Gedung 3 & 1.25 & 0 & 0,75 \\
\hline
\end{tabular}

Tabel 20. Perhitungan Nilai Total Aspek Arsitektur

\begin{tabular}{ccccc}
\hline No. & Gedung & CF & SF & Nilai Arsitektur \\
\hline 1 & Gedung 1 & 1,67 & 1 & 1,40 \\
2 & Gedung 2 & 2,00 & 0 & 1,20 \\
3 & Gedung 3 & 0,83 & 2,5 & 1,50 \\
\hline \multicolumn{5}{c}{ Tabel 21. Perhitungan Nilai Total Aspek Utilitas } \\
\hline No. & Gedung & CF & SF & Nilai Utilitas \\
\hline 1 & Gedung 1 & 0 & 0 & 0 \\
2 & Gedung 2 & 2,5 & 0 & 1,5 \\
3 & Gedung 3 & 0 & 0 & 0 \\
\hline
\end{tabular}

\subsection{Penentuan rangking prioritas perbaikan gedung}

Setelah tiap gedung memiliki nilai total tiap aspek, maka dapat ditentukan prioritas perbaikan gedung berdasarkan pada besaran nilai akhir. Penentuan rangking prioritas perbaikan gedung menggunakan persamaan 10 dengan presentase prioritas aspek struktur 40,1\%, aspek arsitektur 45,1\%, dan aspek utilitas 14,8\% [1]. Hasil penentuan rangking perbaikan gedung ditunjukkan pada tabel 22.

Tabel 22. Perhitungan Rangking Prioritas Perbaikan Gedung

\begin{tabular}{cccccc}
\hline No. & Gedung & Nilai Struktur & Nilai Arsitektur & Nilai Utilitas & Hasil Akhir \\
\hline 1 & Gedung 1 & 1,05 & 1,40 & 0 & 1,05 \\
2 & Gedung 2 & 1,5 & 1,20 & 1,5 & 1,36 \\
3 & Gedung 3 & 0,75 & 1,50 & 0 & 0,98 \\
\hline
\end{tabular}

Berdasarkan hasil pada tabel 22, maka gedung yang menjadi prioritas perbaikan adalah gedung 2 dengan nilai 1,36. Sedangkan prioritas kedua adalah gedung 1 dengan nilai 1,05 dan gedung 3 dengan nilai 0,98 menjadi prioritas ketiga.

\section{KESIMPULAN}

Sistem Pendukung Keputusan metode Profile Matching dapat menjadi mekanisme penentuan prioritas pemeliharaan dan perbaikan gedung dengan membandingkan jarak (gap) antara tingkat variabel ideal dengan nilai variabel alternatif. Dukungan metode AHP dalam menentukan priority vector dapat membantu pengambil keputusan dalam menilai Indeks Kondisi Elemen dan perhitungan rangking prioritas. Variabel-variabel volume kerusakan, faktor koreksi, dan nilai pengurang pada data kerusakan sub elemen, dan elemen gedung berfungsi untuk mengidentifikasi profil alternatif dibandingkan dengan profil target gedung yang membutuhkan tindakan perbaikan. Sesuai hasil perhitungan Profile Matching, ditentukan prioritas alternatif perbaikan gedung adalah gedung 2 dengan nilai 1,36, kemudian gedung 1 dengan nilai 1,05 dan gedung 3 dengan nilai 0,98. Hasil akhir perhitungan Profile Matching dipengaruhi oleh nilai Indeks Kondisi Sub Elemen dan nilai Indeks Kondisi Elemen yang menjadi dasar penentuan gap. Gap aspek struktur gedung 2 bernilai lebih besar dibandingkan dengan gap komponen struktur gedung 2 dan gedung 3. Walapun pada gap aspek 
arsitektur nilai terbesar adalah gedung 3, akan tetapi pada gap aspek utilitas, nilai gap gedung 2 lebih besar daripada nilai gap gedung 1 dan gedung 3 .

Penelitian ini dapat dikembangkan dengan menambahkan variabel berupa standar biaya perbaikan tiap sub elemen, elemen, dan sub komponen serta perhitungan volume kerusakan dibandingkan dengan volume, luas, atau jumlah unit sub elemen, elemen, dan sub komponen. Sehingga hasil akhir penentuan keputusan juga mempertimbangkan ketersediaan anggaran untuk perbaikan gedung.

\section{DAFTAR PUSTAKA}

[1] E., Kusnadi,"Sistem Pendukung Keputusan Pemeliharaan Bangunan Sekolah Negeri (Studi Kasus di Kecamatan Tigaraksa Kabupaten Tangerang)", Tesis, Magister Teknik Sipil Program Pasca Sarjana Universitas Sebelas Maret Surakarta, Surakarta, 2011.

[2] Pemerintah Republik Indonesia,”Undang-Undang Republik Indonesia No. 28 Tahun 2002 Tentang Bangunan Gedung". Jakarta: Setneg RI, 2002.

[3] F., Fahira, "Sistem Utilitas pada Konstruksi Gedung", Jurnal SMartek, Vol. 8, No. 2, hal 97-106, 2010.

[4] Z., Tharo, dan A.PU., Siahaan, "Profile Matching in Solving Rank Problem", IOSR Journal of Electronics and Communication Engineering, Vol. 11, Issue 5, pp 73-76, 2016.

[5] E., Muslim, et al, "Analytic Hierarchy Process (AHP) Pairwise Matrix with One Missing Value", International Journal of Technology, Vol. 8 No. 7, pp. 1356-1360,2017.

[6] B., Zhu, dan Z., Xu, "Analytic hierarchy process-hesitant group decision making", European Journal of Operational Research, Vol. 239 Issue 3, pp. 794-801, 2014.

[7] W., Ho dan M., Xin, "The state-of-the-art integrations and applications of the analytic hierarchy process", European Journal of operational Research, Vol. 267 Issue 2, pp. 399-414,2017.

[8] Rianto, et al, "AHP-TOPSIS on Selection of New University Students and the Prediction of Future Employment", 1st International Conference on Informatics and Computational Sciences (ICICoS), November 2017, IEEE, pp. 126-130, 2017.

[9] T.R., Sahroni dan H., Arif, "Design of Analytical Hierarchy Process (AHP) for Teaching and Learning", 11th International Conference on Knowledge, Information and Creativity Support Systems (KICSS), November 2016, IEEE, pp. 1-4,2016.

[10] U., Yudatama dan R., Sarno, Evaluation Maturity Index and Risk Management for IT Governance Using Fuzzy AHP and Fuzzy TOPSIS (Case Study Bank XYZ), 2015 International Seminar on Intelligent Technology and Its Applications, May 2015, IEEE , pp. 323-327,2015.

[11] D., Wang, et al, "Research on the production and marketing match model of agricultural products based on Analytic Hierarchy Process", 10th International Symposium on Computational Intelligence and Design (ISCID), December 2017, IEEE, pp. 8 - 12,2017.

[12] E., Turban, et al, "Decision Support Systems and Intelligent Systems", 7th Ed., Practice-Hall, New Delhi, India, 2007.

[13] T.L., Saaty dan L.G., Vargas, "Models, Methods, Concepts \& Application of the Analytic Hierarchy Process", New York : Springer, 2012.

[14] Kusrini, “Konsep dan Aplikasi Sistem Pendukung Keputusan”, Penerbit Andi, Yogyakarta, 2007.

[15] Khairul dan Suherman, "Seleksi Pegawai Kontrak Menjadi Pegawai Tetap Dengan Metode Profile Matching", IT Journal Research and Development, Vol. 2, No. 2, pp. 68-77, Maret 2018.

[16] W. Hartono, et al, "Skala Prioritas Pemeliharaan Gedung-Gedung Kantor Kecamatan di Kabupaten Sukoharjo dengan Metode Analitycal Hierarchy Process (AHP)”, Matriks Teknik Sipil, Vol. 5, No. 2, pp. 423-430, Juni 2017. 
